\title{
Registered nurses' perception of their professional role regarding medication management in nursing care of the elderly
}

\author{
I nger Nordin Olsson ${ }^{1}$, I nger Wätterbjörk ${ }^{1}$, Karin Blomberg ${ }^{2}$ \\ 1. Family Medicine Research Centre, School of Health and Medical Sciences, Örebro University, Örebro, Sweden. 2. School \\ of Health and Medical Sciences, Örebro University, Örebro, Sweden.
}

Correspondence: Inger Nordin Olsson. Address: Family Medicine Research Centre, School of Health and Medical Sciences, Örebro University, Box 161370116 Örebro, Sweden. Email: nordin.inger@gmail.com

Received: April 24, $2013 \quad$ Accepted: July 31, $2013 \quad$ Online Published: October 15, 2013

DOI : 10.5430/jnep.v4n2p153 URL: http://dx.doi.org/10.5430/jnep.v4n2p153

\section{Abstract}

Background: The role of the registered nurse (RN) in the municipality regarding medication management in care for the elderly is rarely discussed. Organizational issues related to medication management often contribute more to the management than needs of the patients, nursing skills, and collaboration with the physician in primary care.

Objective: The aim of this study was to describe RNs' perceptions of their professional role, especially regarding medication management in nursing of the elderly.

Design: The study is descriptive with a qualitative approach. Interviews with 16 RNs working at nursing homes were analysed by content analysis.

Results: The findings can be grouped into seven categories showing the RN in different roles while performing different aspects of her or his work: as controller, executer, messenger, supervisor, initiator, visionary and solitary worker. These themes were identified in the interviews and characterized the nurses' own judgements and actions taken, especially regarding drug treatment. Overall, the RNs described nursing in elderly care as an undefined profession lacking leadership regarding medication management.

Conclusions: The study concludes that medication management ought to be promoted in care for the elderly. To handle the challenge and risks of polypharmacy there must be sufficient and adequate reporting based on the RNs' nursing and skills to monitor and evaluate the drug treatment in teamwork with the physician. This requires leadership with understanding of the integration of services in care for the elderly, and of the medical processes and nursing skills involved.

\section{Key words}

Collaboration, Elderly, Medication management, Nursing process and quality

\section{I ntroduction}

During the last 50 years the number of people 65 years and older has increased. The ageing and elderly population place great demands on society and especially on health care to promote healthy and meaningful ageing, according to the World Published by Sciedu Press 
Health Organization's concept of "active ageing”" ${ }^{[1]}$. In Sweden the legislation surrounding the Elderly Reform ${ }^{[2]}$ in the early 1990s meant an enormous change as it transferred the overall responsibility for care of the elderly to the municipalities. The reform demanded a shift from a medical perspective of elderly care to a more social perspective, with medical care provided when needed ${ }^{[2]}$. This had organizational consequences for nursing homes, leadership issues, and issues such as prioritized needs of the elderly. For registered nurses (RNs), the Elderly Reform meant employment with a new caregiver organization. It also meant a new role since RNs in elderly care have the highest nursing education and are expected to act as leaders of the nursing staff without formal mandate. Care of the elderly within the municipalities is a growing area of practice for which no guidelines have as yet been developed ${ }^{[3,4]}$.

The RNs in elderly care in Sweden have been described as working under pressure ${ }^{[5-7]}$ and lacking specialist competence in elderly care ${ }^{[6,8,9]}$. They often work in isolation from colleagues and at a great distance from the physician who needs to be contacted when new medical problems arise. Unlike the RNs who are employed by the municipality, the physicians are medical consultants employed by the county council. The RNs have the medical responsibility for the care given; they also have responsibilities to prescribe different types of care and non-pharmacological treatment. A wide range of possibilities exist for such types of care, though they demand time and strategies for assessment, planning and evaluation ${ }^{[7]}$ by the RNs. This requires leadership with understanding of the integration of services in elderly care. It further requires medical judgement and nursing skills as well as social skills.

With an ageing population the real challenge for the health care system is the burden of chronic diseases and medica tion ${ }^{[10]}$ and, in this context, defining an adequate level of follow-up, taking into consideration normal ageing and the diseases of old age. Modern drugs have made great contributions to health and better quality of life, though an increase in negative side effects due to extensive pharmacological treatment, especially in multi-diseased elderly patients, has been noted ${ }^{[11,12]}$. Chronically ill, often named multi-diseased, nursing home residents are among the individuals who are most dependent on good health care, since they have reduced autonomy, and less ability and possibility to communicate about their conditions or symptoms ${ }^{[13]}$. Multi-medication, or polypharmacy, defined as five drugs or more ${ }^{[14,15]}$, is very common in nursing homes with approximately, $67 \%$ of the residents receiving 10 drugs or more ${ }^{[16]}$. Polypharmacy results in increased risks of inappropriate drug use and adverse drug reactions, followed by higher morbidity ${ }^{[17-20]}$. At nursing homes the use of medication dispensing systems (such as ApoDos) are very common to facilitate the extensive drug handling, though there are known risks with this system, such as more inappropriate drugs ${ }^{[21]}$ and errors when transfer ring ${ }^{[22]}$.

Studies examining different strategies for handling drug treatment in the elderly ${ }^{[23-28]}$ stress the role of the physician ${ }^{[29,30]}$. In this study we focus on the role of the $\mathrm{RN}$ as main caregiver working in collaboration with the consultant physician. The aim of the study was to describe RNs' perceptions of their profession concerning medication management in elderly care in nursing homes.

\section{Methods}

\section{Design and participants}

A descriptive study design with a qualitative approach was used. The study was carried out in Örebro, Sweden. Eight nursing homes with similar workloads but from different parts of the town were selected by the municipal administrators. To obtain different perspectives, as well as a range of work methods, competence and experience, the head of each nursing home was requested to invite two RNs to participate. All invited RNs agreed to take part in the interviews. The RNs represented dementia care and general elderly care units, the two categories of care for the elderly that have developed within the municipality. The sampling was guided and estimated to cover and reflect different perspectives and experiences ${ }^{[31]}$ of the RNs as well as different nursing homes.

The study was approved by the Regional Ethical Committee of Uppsala University, Uppsala, Sweden. 
The participants included 16 RNs who were interviewed, 15 women and 1 man. Their years of working as an RN ranged between 1 and 39 years, with a median of 20 years, while duration of working in the same workplace ranged from a few months to 18 years, with a median of 5 years. No one had education in drug prescribing. Nine had some short courses of nursing education in advanced level, but only one had a specialized degree as nurse (see Table 1).

\section{Procedure}

To gain a deeper understanding of RNs' perceptions of their profession concerning medication management in elderly care the theoretical guiding for the interviews was derived from Kvale ${ }^{[32]}$. All the interviews were performed by the same interviewer, who was familiar with the organization and municipal legislation and experienced in interview technique. The interview guide for the interviews was based on previous studies and expertise ${ }^{[13,33,34]}$ in the field. The guide provided background information on the education and experience of the RNs and employment in the municipality. This was followed by questions about the RNs' perspectives on their work conditions. The main section contained questions about nursing of the elderly with an evident focus on drug treatment, e.g. "What are your opinions on medication management?" The interview ended with questions on possibilities and needs for new strategies to develop the nursing profession in elderly care in the future.

The interviews lasted 20-40 minutes with a mean of 32 minutes and were conducted at the RNs' workplaces at a time determined by the participants. All responses and data were recorded and transcribed verbatim by a research assistant for further qualitative analysis.

Table 1 Characteristics of the Registered Nurses (RNs) in the Municipal Elderly Care

\begin{tabular}{|c|c|c|c|c|c|}
\hline Participant & $\begin{array}{l}\text { Years as } \\
\text { RN }\end{array}$ & $\begin{array}{l}\text { Experience of } \\
\text { community elderly } \\
\text { care (years) }\end{array}$ & $\begin{array}{l}\text { Years in the } \\
\text { same workplace }\end{array}$ & $\begin{array}{l}\text { Education in drug } \\
\text { prescribing (No/Yes) }\end{array}$ & $\begin{array}{l}\text { Education in advanced } \\
\text { level }\end{array}$ \\
\hline RN1 & 36 & 18 & 18 & No & $\begin{array}{l}\text { Courses in diabetes, } \\
\text { incontinence }\end{array}$ \\
\hline RN2 & 18 & 6.5 & 6.5 & No & $\begin{array}{l}\text { Courses in pain, neurology, } \\
\text { surgery }\end{array}$ \\
\hline RN3 & 37 & 13 & 13 & No & Courses in documentation \\
\hline RN4 & 21 & 7 & 1.5 & No & \\
\hline RN5 & 39 & 6 & 5 & No & Course in pharmacology \\
\hline RN6 & 1 & 5 & 1 & No & \\
\hline RN7 & 0 & 10 & 0 & $\begin{array}{l}\text { No, only in } \\
\text { incontinence }\end{array}$ & \\
\hline RN8 & 5 & 18 & 5 & No & \\
\hline RN9 & 34 & 10 & months & No & District nurse \\
\hline RN10 & 15 & 2 & 2 & $\begin{array}{l}\text { No, only in } \\
\text { incontinence }\end{array}$ & \\
\hline RN11 & 10 & 7 & 7 & No & Course in geriatric \\
\hline RN12 & 36 & 5 & 5 & $\begin{array}{l}\text { No, only in } \\
\text { incontinence, stoma }\end{array}$ & \\
\hline RN13 & 27 & 18 & 8 & No & Course in supervision \\
\hline RN14 & 29 & 18 & 2 & $\begin{array}{l}\text { No, only in } \\
\text { incontinence }\end{array}$ & $\begin{array}{l}\text { Courses in palliative care, } \\
\text { documentation }\end{array}$ \\
\hline RN15 & 20 & 6 & 1 & No & $\begin{array}{l}\text { Courses in psychiatric care, } \\
\text { pedagogy, philosophy }\end{array}$ \\
\hline RN16 & 10 & 7 & 7 & No & Courses in nutrition \\
\hline
\end{tabular}




\section{Data analysis}

The text was analysed using the qualitative content analysis method developed by Graneheim and Lundman ${ }^{[35]}$. This analysis includes several steps (for example see Table 2). In the first step the interviews were read through several times to gain a sense of the whole. Meaning units were identified corresponding to the aim of the study. In the second step the meaning units were shortened to condense meaning, yet still preserving their core. In step three the condensed meaning units were coded. The codes were compared for differences and similarities, and sorted into subcategories and, thereafter, abstracted categories. Finally, a latent theme was formulated. The analysis was primarily carried out by the second author. All authors read through the interviews and discussed results throughout the whole process. Quotations were chosen to illustrate the findings and were translated from Swedish to English by an authorized translator.

Table 2. Two Examples Showing the Analysis Process, from Identification of Meaning Units, to Formulation of Subcategories, Categories and, Finally, a Theme, in Describing the Registered Nurses (RNs)' Perceptions of Their Professional Roles, Especially Regarding Medication Management in Elderly Care.

\begin{tabular}{llll}
\hline Meaning units & Subcategories & Categories & Theme \\
\hline $\begin{array}{l}\text { My area of responsibility is to see that there } \\
\text { are drugs, to talk to the doctor, to change } \\
\text { medication according to the doctor's } \\
\text { prescription - that's my part... }\end{array}$ & $\begin{array}{l}\text { Conducts their responsibility in the } \\
\text { administration of prescription drug }\end{array}$ & Executor & $\begin{array}{l}\text { Occupying different } \\
\text { roles in an undefined } \\
\text { profession lacking } \\
\text { leadership }\end{array}$ \\
$\begin{array}{l}\text { It is the staff who signal since they are the } \\
\text { ones who give the drugs and see the first } \\
\text { reaction... }\end{array}$ & $\begin{array}{l}\text { RN delegates drug administration and } \\
\text { the monitoring of effects and side } \\
\text { effects to nursing staff }\end{array}$ & Supervisor & \\
\hline
\end{tabular}

\section{Results}

\section{An undefined profession lacking leadership}

The results can be expressed as one overall theme: occupying different roles in an undefined profession lacking leadership. The findings were grouped into seven categories showing the RN in different roles while performing different aspects of her or his work: as controller, executer, messenger, supervisor, initiator, visionary and solitary worker. The RNs described a self-defined professional role and conditions in which there was no proper organizational leadership regarding nursing and medication management in care of the elderly.

\section{Controller}

The RNs described the role of controlling subordinate nursing staff in their work of administering drugs to elderly people. To avoid mistakes, RNs need to compile the list of medications and furnish clear and unambiguous instructions regarding their administration. Procedures are in place for managing mistakes in drug administration and these are followed to trace the source of any mistakes made. The RN checks whether the subordinate nursing staff have kept a record of all distributed drugs. Where a signature is missing, the RN needs to follow up whether this is a real mistake, or whether the patient has received the drug, and the signature is merely missing. One RN explained, "The lists have to be very clear since the subordinate nurses administer the drugs ... if there are new doctors you have to control it thoroughly so that the drugs are clearly administered.” (RN 9)

\section{Executer}

In working with drug prescriptions from the physicians, the RN's role was described as that of an executer. The responsibility for this task is clearly defined and the RNs were confident in this task. As one RN described it, "My areas of 
responsibility are to see that there are drugs, to talk to the doctor, to change medications according to the doctor's prescription ... that's my part.” (RN 3)

Almost all RNs mentioned the advantages of using the specific system for dispensing medication, called ApoDos, the main advantage of which was that the responsibility for correct dosage in the dispensers lay with the ApoDos system and not with the RN. The disadvantages of the system included drug wastage and the time it took to manage changes in dosage, but none of the RNs stated that they had taken any action to change the system.

\section{Messenger}

The RNs described their role of messenger when they had to pass on information concerning medication from the nursing staff or patients' relatives to the physician. Some RNs took the decision to pass information on to the physician after consulting with the nursing staff or other RNs, while others took the decision by themselves. One RN said, "During our team meetings we go through all the residents and if there is something that we think should be discussed during the ward round, then I write it down and take it up during the round with the doctor.” (RN 7)

\section{Supervisor}

Nursing interventions were described as being initiated mostly by nursing staff or else by relatives of the elderly, in which case the RNs made their own assessment and follow-up. Some RNs stated that they took the initiative for nursing interventions, and later tutored and delegated certain tasks to the nursing staff. Monitoring effects and side effects of drugs was sometimes delegated to subordinate nursing staff or done in conjunction with the staff as a mutual responsibility, although some RNs perceived this as an RN task and responsibility. One RN explained, "It is the nursing staff that most often come and say that this person or that person is ill ... Then I have to go and make an assessment. Most of the time it is the nursing staff that say so, but also relatives.” (RN 14)

\section{I nitiator}

In working with the ward's drug supplies, RNs described the role of active initiator. Registered nurses actively managed the supplies and the RNs were concerned about which drugs are available for the RN to give without prescription from the physician. One RN related, "We have the option to make improvements in terms of what drugs we can administer. That's something we think of the whole time: what we can improve.” (RN 6)

\section{Visionary}

The RNs described visions of changing the living conditions for the elderly in municipal nursing homes. They talked about nursing homes being better staffed to ensure that the elderly could live a more active life and also, that the nursing staff would have some time to, e.g., engage in conversation with the elderly. Some RNs suggested that RNs be educated in different specializations such as diabetic care or pain treatment. One RN said she felt that with better care, fewer drugs would need to be used. Several RNs said they would like to take pride in their work in elderly care: "I would like to create a feeling of pride to work with elderly ... I have no idea how, but I'm sure it's a matter of education.” (RN 15)

\section{Solitary worker}

The RNs described themselves as not being acknowledged by administration, and as working in isolation. They felt that administration often did not understand the RN's position and situation, neither nursing nor medication management and monitoring, possibly because administrators were not usually medical trained. Positive feedback the RNs received for their work came from the patients and not from management. Furthermore, the RNs said they felt that competence development was not a high priority for management. Financial contributions from administration were poor and because of tight schedules the RNs had no opportunity to attend courses to further their education. However, the RNs themselves showed a passive attitude and did not take much action in this matter. When answering questions on drug treatment in the elderly no one even mentioned or took into account the official courses that had been carried out in collaboration with the physicians. As one RN said, "To get to know about the research that is being carried out on the older elderly - I think that would be 
really interesting to find out ... I think they should 'feed' us with that, we shouldn't have to search for it, what research has been done, so that we can choose ourselves, like, Aha, that’s good!” (RN 1)

\section{Discussion}

When exploring the RNs' perceptions of their profession concerning medication management in elderly care, we identified seven categories. Our results show different approaches to and perspectives on the work of the RNs, which often appears to be characterized by absence of own judgement and action taken, especially regarding drug treatment, as well as a lacking organizational leadership for overall nursing and caregiving.

The idea for this study emerged from a previous study ${ }^{[13]}$ on drug treatment in elderly care with focus on the multimedication in multi-diseased elderly individuals. Though involving the physicians, i.e. the prescribers, we did not succeed in achieving the expected improvements regarding drug treatment in that study. Rather, gaps in the care-giving process appeared. Lack of systematic work and differences in work performance became apparent ${ }^{[13]}$. The question arose whether a missing link to enhanced drug treatment in nursing homes is to be found in RNs' perspectives on their work. Whether an RN defines her or himself as more of a "controller" or as primarily an "executer" or, alternatively, a "messenger" or "supervisor" will have consequences on the work delivered. For the "controller" and the "supervisor", the focus is on the subordinate nursing staff, either because of a shortage of resources ${ }^{[36]}$ or because of a personal preference. In both cases, the RN needs to rely on the knowledge of the nursing staff ${ }^{[7]}$. In cases where RNs see themselves chiefly as an "executer" or a "messenger" the drug administration seems to be a passive process for them, involving little own reflection. The "initiator", on the other hand, focuses on the drug supplies - in other words, on having the right drugs and on having enough drugs available when needed. None of these categories emphasizes non-pharmacological treatments or other important aspects of the nursing process ${ }^{[7]}$. The "solitary worker" perspectives of the RNs and the feelings of isolation within an organization with social preferences are significant and alarming. Care taking of multi-diseased elderly individuals requires professional medical knowledge and organizational development. When medical or pharmacological education is considered to be a low priority in the organization this is reason for concern.

The workload of and pressure on the municipalities has increased ${ }^{[36]}$, demanding new strategies in care of the elderly. A previous study ${ }^{[13]}$ showed a clear lack of systematic follow-up and monitoring at nursing homes. Medication management is everyday work for the $\mathrm{RN}{ }^{[37]}$, and not only do the RNs have to perform it safely ${ }^{[5]}$ but they also have to ensure quality drug treatment through discussions with the responsible physician ${ }^{[37,38]}$. There are risks in health care and there are risks for patient safety in municipal elderly care ${ }^{[39]}$ and if the physicians are not aware of the RNs' perceptions of their professional role, drug treatment and evaluation may be hazardous.

In connection with the known risks of multi-medication for the elderly, the shortage of family physicians is often mentioned, firstly implying that no physician takes overall responsibility ${ }^{[33,40]}$. Family physicians' opinions about responsibility regarding patients' complete medications ${ }^{[41]}$ have been categorized into: imposed responsibility, responsibility for own prescriptions, responsibility for all drugs, different but shared responsibility and patient transferring drug information. The consequences of these opinions from the physicians when added to our results of RNs perceptions imply several risks and hazardous possibilities regarding drug treatment in the elderly. For vulnerable chronically ill elderly people it is a question of highest importance and patient safety that responsibility, communication and collaboration concerning drug treatment is totally congruent for the professions and individuals involved. Our focus was on the RNs and their medication management including medication monitoring and thoughts concerning polypharmacy. Seven different categories illuminated, meaning no insurance concerning uniform acting and reporting in medication management.

Some risks of the medication dispensing system (ApoDos) were described before but the system has also been criticized by physicians for being rigid and not encouraging reduction or removal of drugs ${ }^{[40]}$. Still, for the RNs in our study population, the advantages of the ApoDos outweighed its disadvantages. The main advantage for the RNs was that 
ApoDos reduces the RN's responsibility in drug handling and makes delegation to the nursing staff possible. Our results suggest that the RNs considered these advantages more important than the risks of persistent polypharmacy and inappropriate medication. The findings are astonishing since the dispensing system in no way reduces or changes the RNs' professional responsibility according to medication management. To provide appropriate drug treatment, the physicians are dependent on the RNs' judgment and actions ${ }^{[40]}$. Following this, to avoid the prescribing cascade, RNs as medical professionals need to understand symptoms and effects as well as negative side effects of drugs ${ }^{[22]}$. When RNs rely on the nursing staff an important part of the RNs' nursing skills in doing a check-up and alerting the physician is lost.

One strength of our study is that it was a follow-up of a previous study with new perspectives added. The study population included RNs from different workplaces with broad and different experiences who were given the opportunity to describe their perceptions of their profession in their own words. Another strength is the constitution of the research team with different levels of pre-understanding due to different clinical experiences and educational backgrounds, i.e. the two different professions involved which strengthened the validation. A limitation may be the use of an external interviewer, resulting in possible loss of follow-up questions. An advantage of this, however, was a neutral interview position in respect of professional obligations and contradictions. A further limitation may be that the RNs were chosen by the heads of the nursing homes, implying the risk of a "gatekeeper" influencing the results, though our results did not show any signs of this. Furthermore, the content analysis of the interviews made it possible to see patterns in the RNs' work.

The challenges in the care of multi-diseased elderly individuals under multi-medication are enormous. More attention needs to be focused on the importance and complexity of the nursing processes in nursing homes and how they are viewed by the RNs as well as the care organization. The clinical aspects of elderly care must be promoted, otherwise health assessment and medication management may be neglected. There must be sufficient and adequate reporting based on the RNs' nursing and medical skills to monitor and evaluate as well as question the drug treatment in teamwork with the physician.

In definitions of the nursing process ${ }^{[7]}$, medical assessment, treatment and evaluation are emphasized as fundamental to care giving. The main findings of the present study indicate that there is a need for both professional and organizational re-thinking ${ }^{[43]}$. Re-thinking sometimes means returning to basic principles of professional performance and leadership, and not necessarily developing a new model.

\section{Acknowledgements}

This study was supported by the Örebro County Council. We would like to express our gratitude to Örebro municipality for permitting the interviews. Special thanks go to Gunilla Fahlström for help in designing the interview guide. Many thanks to Lena Hammarlund for performing the interviews and to Susanne Collgård for transcribing them. We are grateful to the RNs for agreeing to participate and sharing their perceptions of their professional role with us.

\section{References}

[1] World Health Organization. Active Ageing. A Policy Framework. In: WHO, ed.; 2002.

[2] Andersson G, Karlberg I. Integrated care for the elderly: the background and effects of the reform of Swedish care of the elderly. International Journal of Integrated Care. 2000; 1: 1-10.

[3] Mitty EL, Reinhard SC, Young HM, Kane RA, Quinn WV, Graneheim UH, et al. Policy perspectives: Assisted living and the role of nursing. Nurse delegation of medication administration for older adults in assisted living. The American Journal of Nursing 2003; 103: 32-43; quiz 44.

[4] Reinhard SC, Young HM, Kane RA, Quinn WV. Nurse delegation of medication administration for older adults in assisted living. Nursing Outlook. 2006; 54: 74-80. PMid:16597525 http://dx.doi.org/10.1016/j.outlook.2005.05.008

[5] Dilles T, Elseviers MM, Van Rompaey B, Van Bortel LM, Stichele RR. Barriers for nurses to safe medication management in nursing homes. Journal of Nursing Scholarship. 2011; 43: 171-180. PMid:21605321

http://dx.doi.org/10.1111/j.1547-5069.2011.01386.x 
[6] Josefsson K, Sonde L, Wahlin TB. Registered nurses' education and their views on competence development in municipal elderly care in Sweden: a questionnaire survey. International Journal of Nursing Studies. 2007; 44: 245-258. PMid:16426617 http://dx.doi.org/10.1016/j.ijnurstu.2005.11.029

[7] Nilsson K, Lundgren S, Furaker C. Registered nurses' everyday activities in municipal health care: a study of diaries. International Journal of Nursing Practice. 2009; 15: 543-552. PMid:19958409 http://dx.doi.org/10.1111/j.1440-172X.2009.01777.x

[8] The National Board of Health and Welfare. Medical responsible nurse in the municipality. In: Socialstyrelsen, ed. Stockholm: Socialstyrelsen; 1997.

[9] The Swedish Association of Health Professionals. The registrered nurses in elderly care; 2004.

[10] Hagstrom B, Mattsson B, Wimo A, Gunnarsson RK. More illness and less disease? A 20-year perspective on chronic disease and medication. Scandinavian Journal of Public Health. 2006; 34: 584-588. PMid:17132591 http://dx.doi.org/10.1080/14034940600703407

[11] The National Board of Health and Welfare. Drug treatment of the elderly, a follow-up. In: Socialstyrelsen, ed.: http://www.socialstyrelsen.se/NR/rdonlyres/6B9DA61E-F92C-46C8-BAC9-3A443EC1D2F8/3032/200410319.pdf; 2004. p. 1-75.

[12] The National Board of Health and Welfare. Drug treatment in care of the elderly. In: Socialstyrelsen, ed.: http://www.socialstyrelsen.se/NR/rdonlyres/F2DB1284-162C-426C-BE00-E988CFB84A3A/2666/200410916.pdf; 2004. p. 1-29.

[13] Nordin Olsson I, Curman B, Engfeldt P. Patient focused drug surveillance of elderly patients in nursing homes. Pharmacoepidemiology and Drug Safety. 2010; 19: 150-157. PMid:20014180 http://dx.doi.org/10.1002/pds.1891

[14] Agostini JV, Han L, Tinetti ME. The relationship between number of medications and weight loss or impaired balance in older adults. Journal of the American Geriatrics Society. 2004; 52: 1719-1723. PMid:15450051 http://dx.doi.org/10.1111/j.1532-5415.2004.52467.x

[15] Hovstadius B, Astrand B, Petersson G. Assessment of regional variation in polypharmacy. Pharmacoepidemiology and Drug Safety. 2010; 19: 375-383. PMid:20191596

[16] The National Board of Health and Welfare. Kvaliten i äldres läkemedelsanvändning - Källa-projektet (2004-131-24) (in Swedish). 2004 http://www.socialstyrelsen.se/publikationer2004/2004-131-24 last accessed).

[17] Franic DM, Jiang JZ. Potentially inappropriate drug use and health-related quality of life in the elderly. Pharmacotherapy 2006; 26: 768-778. PMid:16716130 http://dx.doi.org/10.1592/phco.26.6.768

[18] Hamilton HJ, Gallagher PF, O’Mahony D. Inappropriate prescribing and adverse drug events in older people. BMC Geriatrics. 2009; 9: 5. PMid:19175914 http://dx.doi.org/10.1186/1471-2318-9-5

[19] Liu GG, Christensen DB. The continuing challenge of inappropriate prescribing in the elderly: an update of the evidence. Journal of American Pharmacists Association. 2002; 42: 847-857. http://dx.doi.org/10.1331/108658002762063682

[20] O'Mahony D, Gallagher PF. Inappropriate prescribing in the older population: need for new criteria. Age Ageing. 2008; 37: 138-141. PMid:18349010 http://dx.doi.org/10.1093/ageing/afm189

[21] The National Board of Health and Welfare, Regions SAoLAa. Open comparisons of quality and efficiency in the health care system. In: Welfare TNBoHa, Regions SAoLAa, eds. Stockholm; 2008.

[22] Midlöv P, Bergkvist A, Bondesson Å, Eriksson T, Höglund P. Medication errors when transferring elderly patients between primary health care and hospital care. Pharmacy World and Science. 2005; 27: 116-120. http://dx.doi.org/10.1007/s11096-004-3705-y

[23] Crotty M, Halbert J, Rowett D, Giles L, Birks R, Williams H, et al. An outreach geriatric medication advisory service in residential aged care: a randomised controlled trial of case conferencing. Age Ageing. 2004; 33: 612-617. PMid:15385274 http://dx.doi.org/10.1093/ageing/afh213

[24] Holland R, Lenaghan E, Harvey I, Smith R, Shepstone L, Lipp A, et al. Does home based medication review keep older people out of hospital? The HOMER randomised controlled trial. Bmj. 2005; 330: 293-295. PMid:15665005 http://dx.doi.org/10.1136/bmj.38338.674583.AE

[25] King MA, Roberts MS. Multidisciplinary case conference reviews: improving outcomes for nursing home residents, carers and health professionals. Pharmacy World and Science. 2001; 23: 41-45. http://dx.doi.org/10.1023/A:1011215008000

[26] Lenaghan E, Holland R, Brooks A. Home-based medication review in a high risk elderly population in primary care--the POLYMED randomised controlled trial. Age Ageing. 2007; 36: 292-297. PMid:17387123 http://dx.doi.org/10.1093/ageing/afm036

[27] Nazareth I, Burton A, Shulman S, Smith P, Haines A, Timberal H. A pharmacy discharge plan for hospitalized elderly patients--a randomized controlled trial. Age Ageing. 2001; 30: 33-40. http://dx.doi.org/10.1093/ageing/30.1.33

[28] Salter C, Holland R, Harvey I, Henwood K. “I haven’t even phoned my doctor yet.” The advice giving role of the pharmacist during consultations for medication review with patients aged 80 or more: qualitative discourse analysis. British Medical Journal. 2007; 334: 1101-1104. PMid:17449504 http://dx.doi.org/10.1136/bmj.39171.577106.55 
[29] Bondesson Å, Midlöv P, Eriksson T, Höglund P. Pharmacotherapeutic interventions by a multi-specialty team: opinions of the general practitioners and nurses. European Journal of Clinical Pharmacology. 2003; 59: 65-69. PMid:12682805

[30] Midlöv P, Bondesson Å, Eriksson T, Nerbrand C, Höglund P. Effects of educational outreach visits on prescribing of benzodiazepines and antipsychotic drugs to elderly patients in primary health care in southern Sweden. Family practice. 2006; 23: 60-64. PMid:16332945 http://dx.doi.org/10.1093/fampra/cmi105

[31] Patton MQ. Qualitative Research \& Evalutation Methods 3: th ed. Thosand Oaks, Ca, USA: Sage Publications, Inc., 2002.

[32] Kvale S, Brinkman S. InterViews. Learning the Craft of Qualitative Research Interviewing. Second edition ed. London: Sage Pubns., 2008.

[33] Nordin Olsson I, Runnamo R, Engfeldt P. Medication quality and quality of life in the elderly, a cohort study. Health and Quality of Life Outcomes. 2011; 9: 95. PMid:22054205 http://dx.doi.org/10.1186/1477-7525-9-95

[34] Nordin Olsson I, Runnamo R, Engfeldt P. Drug treatment in the elderly; An intervention to enhance prescription quality and quality of life. Scand J Prim Health Care. 2012; 30: 3-9. PMid:22175269 http://dx.doi.org/10.3109/02813432.2011.629149

[35] Graneheim UH, Lundman B. Qualitative content analysis in nursing research: concepts, procedures and measures to achieve trustworthiness. Nurse Education Today. 2004; 24: 105-112. PMid:14769454 http://dx.doi.org/10.1016/j.nedt.2003.10.001

[36] Josefsson K, Sonde L, Winblad B, Robins Wahlin TB. Work situation of registered nurses in municipal elderly care in Sweden: a questionnaire survey. International Journal of Nursing Studies. 2007; 44: 71-82. PMid:16376347 http://dx.doi.org/10.1016/j.ijnurstu.2005.10.014

[37] Griffiths R, Johnson M, Piper M, Langdon R. A nursing intervention for the quality use of medicines by elderly community clients. International Journal of Nursing Practice. 2004; 10: 166-176. PMid:15265227 http://dx.doi.org/10.1111/j.1440-172X.2004.00476.x

[38] Halvorsen KH, Ruths S, Granas AG, Viktil KK. Multidisciplinary intervention to identify and resolve drug-related problems in Norwegian nursing homes. Scandinavian Journal of Primary Health Care. 2010; 28: 82-88. PMid:20429739 http://dx.doi.org/10.3109/02813431003765455

[39] Handler SM, Castle NG, Studenski SA, Perera S, Fridsma DB, Nace DA, et al. Patient safety culture assessment in the nursing home. Quality and Safety in Health Care. 2006; 15: 400-404. PMid:17142586 http://dx.doi.org/10.1136/qshc.2006.018408

[40] The National Board of Health and Welfare. Quality of drug treatment of the elderly. The role of the physician. 2011.

[41] Rahmner PB, Gustafsson LL, Holmstrom I, Rosenqvist U, Tomson G. Whose job is it anyway? Swedish general practitioners' perception of their responsibility for the patient's drug list. The Annals of Family Medicine. 2010; 8: 40-46. PMid:20065277 http://dx.doi.org/10.1370/afm.1074

[42] Rochon PA, Gurwitz JH. Optimising drug treatment for elderly people: the prescribing cascade. British Medical Journal. 1997; 315: 1096-1099. http://dx.doi.org/10.1136/bmj.315.7115.1096

[43] Finnbakk E, Skovdahl K, Störe Blix E, Fagerström L. Top-level managers' and politicians’ worries about future care for older people with complex and acute illnesses - a Nordic study. International Journal of Older People Nursing. 2011: 1-10. 